\title{
Quality of life of Family Health Strategy professionals: a systematic review
}

\author{
Ana Carolina Chagas Pinatto Balabem', Murilo Navarro de Oliveira", Álex Moreira Herval'", Ítalo de Macedo Bernardino'v, \\ Walbert de Andrade Vieirav", Renata Prata Cunha Bernardes Rodrigues" ${ }^{\mathrm{V}}$, Luiz Renato Paranhos ${ }^{\mathrm{VII}}$
}

Universidade Federal de Uberlândia (UFU), Uberlândia (MG), Brazil

'DDS. Master's Student, Postgraduate Program on Public Health Management, Universidade Estadual de Campinas (UNICAMP), Campinas (SP), Brazil

(D) http://orcid.org/0000-0003-3145-4809

"MSc. Doctoral Student, Postgraduate Program on Dentistry, School of Dentistry, Universidade Federal de Uberlândia (UFU), Uberlândia (MG), Brazil.

(D) http://orcid.org/0000-0002-8555-3960

"'PhD. Professor, Department of Preventive and Community Dentistry, School of Dentistry, Universidade Federal de Uberlândia (UFU), Uberlândia (MG), Brazil.

(D) http://orcid.org/0000-0001-6649-2616

"MSc. Doctoral Student, Department of Dentistry, Universidade Estadual da Paraíba (UEPB), Campina Grande (PB), Brazil.

(D) http://orcid.org/0000-0003-4750-5666

'MSc. Doctoral Student, Department of Restorative Dentistry, Endodontics Division, School of Dentistry of Piracicaba, Universidade Estadual de Campinas (UNICAMP), Piracicaba, Brazil.

(D) http://orcid.org/0000-0001-8872-2865

"MSc. Professor, Department of Preventive and Community Dentistry, School of Dentistry, Universidade Federal de Uberlândia (UFU), Uberlândia, Brazil.

(D) http://orcig.og/0000-0002-9721-6435

VIIPhD. Professor, Department of Preventive and Community Dentistry, School of Dentistry, Universidade Federal de Uberlândia (UFU), Uberlândia, Brazil.

(D) http://orcid.org/0000-0002-7599-0120

KEY WORDS (MeSH terms):

Primary health care.

Family health.

Health Personnel.

\section{AUTHORS' KEY WORDS:}

Basic attention.

Primary healthcare.

Health professionals.

Health teams.

Workers'health.

\begin{abstract}
BACKGROUND: Individuals' quality of working life and motivation are directly related to their satisfaction and wellbeing. Although studies on the quality of life of family health workers have been conducted, there are none correlating these professionals' wellbeing with this work model.

OBJECTIVE: To review the scientific literature in order to identify the levels of quality of life, in their dimensions, of Family Health Strategy workers.

DESIGN AND SETTING: Systematic review of observational studies developed through a partnership between two postgraduate schools (Piracicaba and Uberlândia).

METHODS: The review followed the PRISMA recommendations and was registered in the PROSPERO database. Ten databases were used, including the "grey literature". Two evaluators selected the eligible studies, collected the data and assessed the risk of biases, independently. The JBI tool was used to assess the risk of bias. A complementary statistical analysis was conducted on the means and standard deviations of the results from the WHOQOL-100 and WHOQOL-bref questionnaires.

RESULTS: The initial search presented 1,744 results, from which eight were included in the qualitative analysis. The studies were published between 2007 and 2018. The total sample included 1,358 answered questionnaires. All the studies presented low risk of bias. The complementary analysis showed that the environmental factor (mean score $56.12 \pm 2.33$ ) had the most influence on the quality of life of community health workers, while physical health (mean score $14.29 \pm 0.21$ ) had the most influence on graduate professionals.
\end{abstract}

CONCLUSION: Professionals working within the Family Health Strategy had dimensions of quality of life that varied according to their professional category.

SYSTEMATIC REVIEW REGISTRATION: CRD42019123243.

\section{INTRODUCTION}

Over the last decades, Brazil has faced the challenge of changing the public healthcare model, i.e. to migrate from the Flexnerian model focused on procedures and specialized care to a comprehensive care model based on understanding the social determinants of health. ${ }^{1,2}$ One of the crucial points in this change is to strengthen primary healthcare, for which the main operational strategy is the family health model. ${ }^{3-5}$ This strategy makes it possible to expand access to healthcare services and implement actions towards comprehensive healthcare. ${ }^{6,7}$

Expansion of this model has been associated with a $45 \%$ reduction in hospitalizations for conditions that are sensitive to resolution within primary healthcare, over a 15 -year period. ${ }^{5}$ Data from the Ministry of Health indicated that in 2019 there were 43,754 family health teams operating throughout the country. These teams were responsible for providing primary healthcare to $64.47 \%$ of the Brazilian population. ${ }^{8}$

Family health work demands different skills for developing innovative community care practices, which makes the work complex and challenging. ${ }^{9}$ Primary healthcare professionals present high prevalence (52.9\%) of chronic stress associated with their work. ${ }^{10}$ Analysis on this prevalence according to professional category shows that even higher prevalence can be observed: $54 \%$ among nurses and $67 \%$ among doctors. ${ }^{11,12}$ However, studies conducted among Brazilian professionals in family health teams have shown lower prevalence of burnout syndrome, varying according to the region of Brazil. In one municipality in the northeastern region, the prevalence of professionals with medium and high levels of burnout was observed to be $37.9 \%{ }^{13}$ In a municipality in southeastern Brazil, the prevalence of this syndrome reached $41.6 \%{ }^{14}$ 
In this regard, it is important to understand that the way in which work is organized affects both the workers' quality of life and the service provided. These are therefore important objects of investigation. ${ }^{15,16}$ It can thus be seen that adequate provision of services requires maintenance of the quality of life of family health professionals. ${ }^{17}$

Individuals' quality of working life and motivation are directly related to their satisfaction and wellbeing. Dissatisfaction in a team harms the evolution and productivity of the institution. ${ }^{18}$ Although studies on the quality of life of family health workers have been conducted, there are no studies correlating the wellbeing of these professionals with this work model, ${ }^{19}$ or proposing actions directed to the quality of life of these workers.

\section{OBJECTIVE}

The aim of the present systematic review was to identify the levels of quality of life, in each of their dimensions, of Family Health Strategy workers.

\section{METHODS}

\section{Protocol registration}

This systematic review was performed in accordance with the Preferred Reporting Items for Systematic Reviews and MetaAnalyses (PRISMA) ${ }^{20}$ and the Joanna Briggs Institute Manual for Evidence Synthesis. ${ }^{21}$ The systematic review protocol was registered in the PROSPERO database under \# CRD42019123243.

\section{Study design and eligibility criteria}

This systematic review aimed to answer the following research question: "What are the levels of quality of life of professionals working in the Family Health Strategy?" This question was based on the "Population, Variable and Outcome" strategy, in which the population included in the study was primary healthcare professionals, the variable was the work in the Family Health Strategy and the outcome was quality of life, considering its different dimensions.

The inclusion criteria defined for selection of studies were that these should only be cross-sectional observational studies developed in Brazil, with quality-of-life questionnaires applied to professionals working in the Family Health Strategy. There were no restrictions on year or language. The following types of study were excluded: 1) experimental or non-cross-sectional studies; 2) studies that did not answer the research question; 3 ) studies on instrument validation; and 4) qualitative studies.

\section{Sources of information and search strategies}

The primary study sources used were the PubMed (including MEDLINE), Scopus, Embase, SciELO, Web of Science, LILACS (Latin American and Caribbean Literature in Health Sciences) and Science Direct databases. The OpenThesis, OpenGrey, and OATD (Open
Access Theses and Dissertations) databases were used to partially capture the "grey literature". The MeSH (Medical Subject Headings), DeCS (Health Sciences Descriptors) and Emtree (Embase Subject Headings) resources were used to select adequate search descriptors. The Boolean operators "AND" and "OR" were used to enhance the research strategy through several combinations, as shown in Table 1. The search was performed in January 2020. The results obtained were exported to the EndNote Web ${ }^{\text {Ta }}$ software (Thomson Reuters, Toronto, Canada), in which duplicates were removed.

\section{Study selection}

The studies were selected in three stages. A calibration exercise was performed before the selection of studies, in which the reviewers discussed the eligibility criteria and applied them to a sample of $20 \%$ of the results retrieved to determine inter-examiner agreement. After an adequate level of agreement (kappa $\geq$ 0.81 ) had been reached, the first stage was started. In this, two reviewers (ACCPB and WAV) analyzed all the titles of the studies, independently. Any divergences between these examiners were discussed with a third reviewer (AMH) to reach a consensus. Studies that were not excluded in this phase continued to the next one. In the second phase, the same reviewers (ACCPB and WAV) read the abstracts, independently. The abstracts that did not meet the eligibility criteria were eliminated. Articles in which the titles met the objectives of the study but for which the abstract was unavailable were fully analyzed in the next phase. In the third phase, the preliminarily eligible studies were fully read to verify whether they met the eligibility criteria. In cases of disagreement between the two reviewers, a third one (AMH) was consulted to make a final decision. The studies rejected were registered separately, with explanations of the reasons for exclusion.

\section{Data collection}

To ensure consistency between the reviewers in the data collection process, a calibration exercise was performed, in which the reviewers (ACCPB and AMH) extracted information from an eligible study together. After the selection, the studies were analyzed and the two reviewers (ACCPB and AMH) extracted the following information from each of them: study identification (author, year and location), sex, number of questionnaires answered, occupation, types of questionnaires used, mean results regarding quality of life obtained from the questionnaires, application of additional questionnaires and collection of socioeconomic data from the sample.

\section{Risk of individual bias of the studies}

The risk of bias and individual quality of each study included were assessed using the JBI critical appraisal tools for use in systematic reviews on cross-sectional observational studies. ${ }^{22}$ Two authors 
(AMH and $\mathrm{MNO}$ ) independently assessed each domain, in accordance with the PRISMA recommendations. ${ }^{20}$ The risk of bias was categorized as high when the study reached a "yes" score of up to $49 \%$, moderate when the study reached a "yes" score of $50 \%$ to $69 \%$ and low when the study reached a "yes" score of more than $70 \%$.

The question assessing the inclusion criteria for the study participants (Q1) was considered to have been answered "yes" (criteria verified) when the studies included the universe of family health professionals. The question referring to exposure factors (Q3) was considered "not applicable" because this systematic review aimed to identify factors that influence the quality of life, but only the dimensions most affected. Similarly, the questions about identification (Q5) and treatment (Q6) of the confounding factors were considered "not applicable" because they would identify the validity of the exposure studied.

\section{Qualitative synthesis and complementary statistical analysis}

Data were extracted from the individual studies and then a synthesis of results was performed. Considering that all the eligible studies performed descriptive analyses to determine the levels of quality-of-life domains, without comparison between the groups, it was considered unviable to conduct a meta-analysis on continuous outcomes in order to estimate the effects of differences. Thus, the quality-of-life domains in the WHOQOL-bref questionnaire (physical, social, environmental and psychological) and WHOQOL-100 questionnaire (physical, psychological, level of independence, social, environmental and spiritual) were analyzed complementarily, considering the mean and standard deviation values expressed in the primary studies. It was possible to calculate means that were weighted according to the sample size of the scores reported in each study, with the aim of obtaining an overall estimate of the quality-of-life domains. Hence, the STATA software, version 15.0 (StataCorp, College Station, United States), was used.

\section{RESULTS}

\section{Study selection}

In the initial phase of study identification, after exploring the ten electronic databases, 1,744 results were found. Next, duplicate articles were excluded, which left 1,373 studies for the analysis on titles and abstracts. From these, 12 remained for full-text reading. After reading the full texts, a further four articles were excluded (Table 2). ${ }^{17,23-25}$

Table 1. Database search strategies

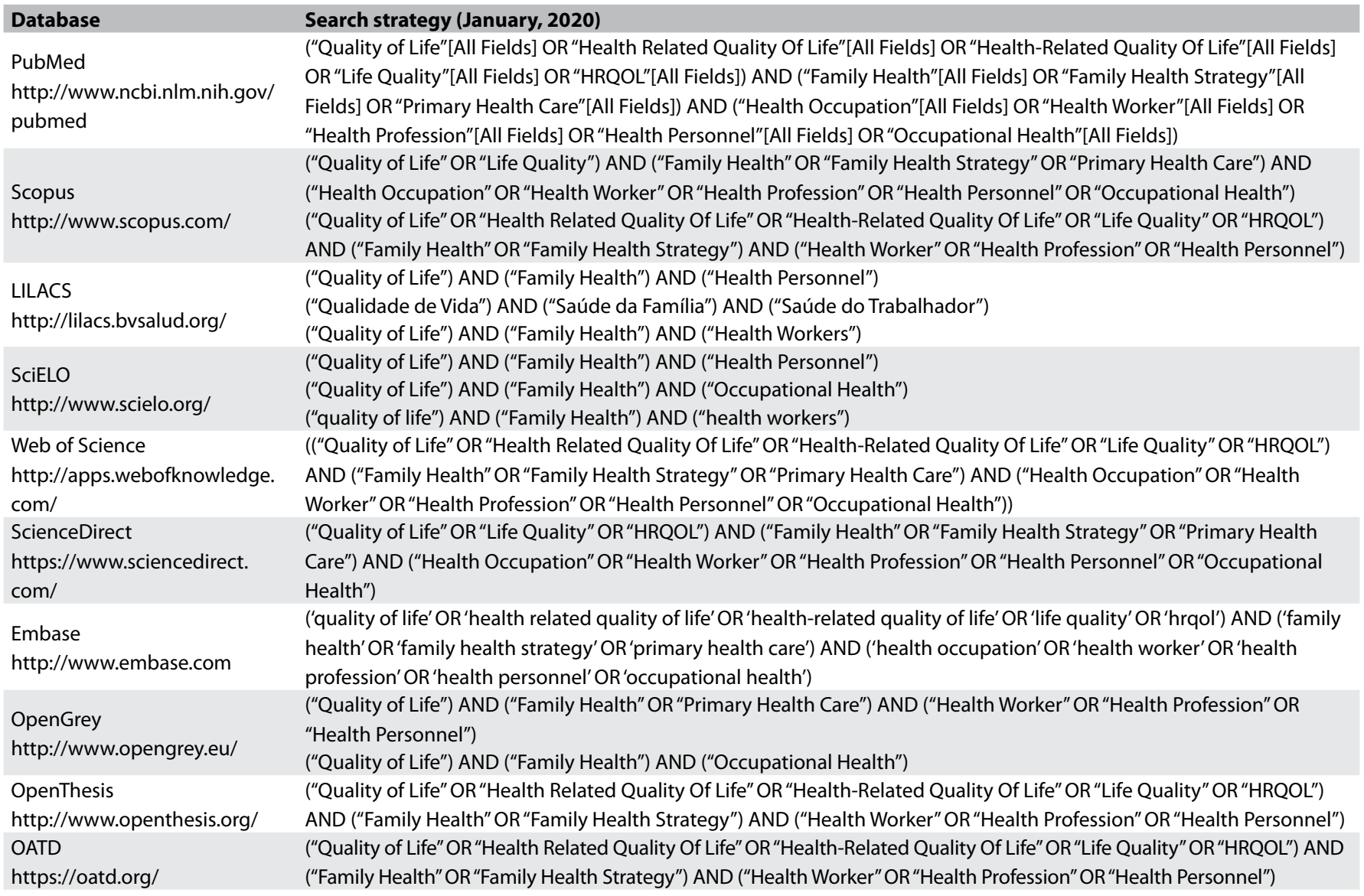


Thus, eight studies ${ }^{26-33}$ were selected for the qualitative analysis, but only five of these were retained for the complementary analysis stage. One of the three studies that were not retained for this final stage ${ }^{27}$ differed from the others regarding the instrument for measuring the quality of life. The other studies that were not retained ${ }^{28,29}$ did not present the data on quality of life in full. Figure 1 shows the entire process of identification, selection and eligibility of the studies.
Table 2. Full texts excluded and reasons for exclusion

\begin{tabular}{|c|c|}
\hline Author & Reason for exclusion \\
\hline Martin et al..$^{25}$ & $\begin{array}{l}\text { The instrument used in the study did not } \\
\text { address quality of life }\end{array}$ \\
\hline Fernandes et al. ${ }^{17}$ & Instrument validation \\
\hline Mota et al..$^{23}$ & Instrument validation \\
\hline Ejlertsson et al. ${ }^{24}$ & Duplicate publication \\
\hline
\end{tabular}

\section{Identification of studies via databases and registers}

\begin{tabular}{|c|c|}
\hline \multicolumn{2}{|c|}{ Records identified from: } \\
\hline $\begin{array}{l}\text { Main databases }(n=1,687) \text { : } \\
\text { - PubMed }(n=204) \\
\text { - Scopus }(n=329) \\
\text { - Embase }(n=112) \\
\text { - SciELO }(n=29) \\
\text { - Web of Science }(n=14) \\
\text { - LILACS }(n=121) \\
\text { - Science Direct }(n=878)\end{array}$ & $\begin{array}{l}\text { Grey literature }(n=57) \text { : } \\
\text { - OpenGrey }(n=0) \\
\text { - OpenThesis }(n=2) \\
\text { - OATD }(n=55)\end{array}$ \\
\hline
\end{tabular}

\section{Records removed before screening:}

Main databases:

- Duplicate records removed by automated tools $(n=117)$ - Duplicate records removed manually $(n=254)$

Grey literature:

- Duplicate records removed manually $(n=0)$

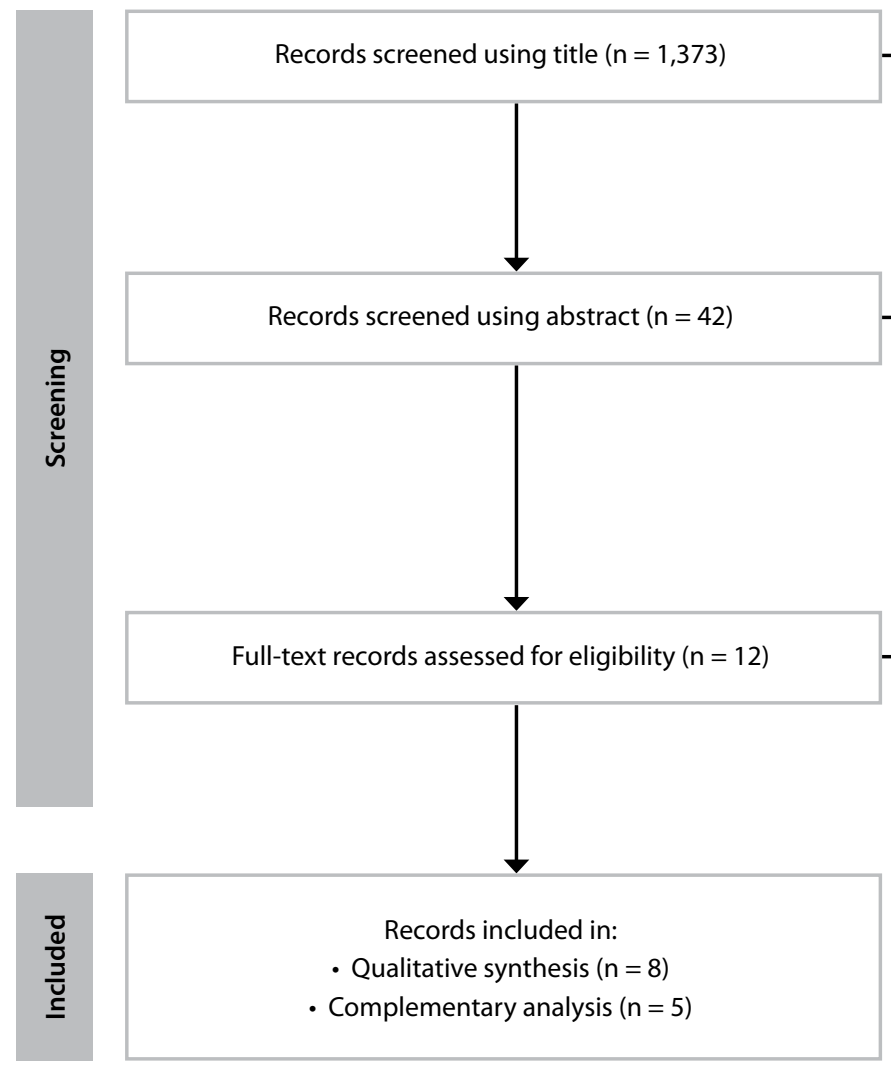

Records excluded: $(n=1,131)$

Records excluded, with reasons $(n=30)$ :

- Not related to the topic $(n=14)$

- Books/book chapter $(n=4)$

- Literature reviews $(n=7)$

- Qualitative studies $(n=5)$

Records excluded, with reasons $(n=4)$ :

- Instrument validation $(n=2)$

- The instrument used in the study did not address quality of life $(n=1)$

- Duplicate publication $(n=1)$

Figure 1. Flowchart of the literature search and selection process adapted from the PRISMA statement. 


\section{Characteristics of eligible studies}

The eligible studies were published between 2007 and 2018. ${ }^{26-}$ ${ }^{33}$ The total sample included 1358 questionnaires answered by Family Health Strategy workers. Their average age ranged from 28 to 33 years (Table 3). ${ }^{26,33}$ All eight studies had been approved by ethics committees and the workers had signed an informed consent statement. The category of workers with the highest number of participants was community health workers $(n=557)$, but nurses $(n=180)$ and physicians $(n=162)$ also answered the questionnaires. All of the studies were conducted using questionnaires. Five studies ${ }^{28-31,33}$ used the WHOQOL-bref protocol, which is a reduced version of the WHOQOL-100 questionnaire, which was used in two studies. ${ }^{26,32}$ A single study used Walton's Quality of Work Life scale (Walton's QWL) as the methodology. ${ }^{27}$

\section{Risk of individual bias of the studies}

All eight studies presented low risk of bias. The studies by Kluthcovsky et al., ${ }^{30}$ Ursine et al. ${ }^{33}$ and Morais et al. ${ }^{28}$ obtained positive evaluations in all the criteria analyzed. The studies by Vasconcelos and Costa-Val, ${ }^{31}$ Figueiredo et al., ${ }^{27}$ Miranzi et al., ${ }^{32}$ Fernandes et al. ${ }^{26}$ and Teles et al..$^{29}$ obtained positive evaluations for $80 \%$ of their questions. The question assessed as negative in these five studies ${ }^{26,27,29,31,32}$ related to the description of study location and subjects (Q2) because the studies did not inform these data, especially concerning study subjects (Table 4).

\section{Result measurement and qualitative synthesis}

The study by Figueiredo et al. ${ }^{27}$ used Walton's QWL, which contains the following domains: adequate and fair compensation,

Table 3. Summary of the main characteristics of the eligible studies

\begin{tabular}{|c|c|c|c|c|c|c|}
\hline Author & State & $\begin{array}{c}\text { Sample size } \\
\text { (Total; \%F; \%M) }\end{array}$ & $\begin{array}{c}\text { Number of } \\
\text { questionnaires } \\
\text { answered }\end{array}$ & Professionals assessed & $\begin{array}{l}\text { Quality-of-life } \\
\text { questionnaire }\end{array}$ & $\begin{array}{c}\text { Other information } \\
\text { collected }\end{array}$ \\
\hline $\begin{array}{l}\text { Kluthcovsky } \\
\text { et al. }{ }^{30}\end{array}$ & Paraná & $169 ; 89.3 \% ; 10.6 \%$ & 169 & Community health workers & WHOQOL-bref & Not informed \\
\hline $\begin{array}{l}\text { Vasconcelos } \\
\text { and Costa-Val. }{ }^{31}\end{array}$ & $\begin{array}{l}\text { Minas } \\
\text { Gerais }\end{array}$ & $60 ; 96.7 \% ; 3.3 \%$ & 60 & Community health workers & WHOQOL-bref & Socioeconomic data \\
\hline $\begin{array}{l}\text { Figueiredo } \\
\text { et al. }^{27}\end{array}$ & $\begin{array}{c}\text { São } \\
\text { Paulo }\end{array}$ & $42 ; 100 \% ; 0 \%$ & 42 & Community health workers & $\begin{array}{c}\text { Walton's QWL } \\
\text { perception scale }\end{array}$ & Not informed \\
\hline Miranzi et al. ${ }^{32}$ & $\begin{array}{l}\text { Minas } \\
\text { Gerais }\end{array}$ & $77 ; 54.8 \% ; 45.2 \%$ & 73 & Physicians & WHOQOL-100 & Additional questionnaire \\
\hline Ursine et al. ${ }^{33}$ & Paraná & $77 ; 86.3 \% ; 13.7 \%$ & 73 & Community health workers & WHOQOL-bref & Sociodemographic data \\
\hline Fernandes et al. ${ }^{26}$ & $\begin{array}{l}\text { Minas } \\
\text { Gerais }\end{array}$ & $113 ; 92.2 \% ; 7.8 \%$ & 90 & Nurses & WHOQOL-100 & Sociodemographic data \\
\hline Teles et al. ${ }^{29}$ & $\begin{array}{l}\text { Minas } \\
\text { Gerais }\end{array}$ & $797 ; 79.9 \% ; 20.3 \%$ & 762 & $\begin{array}{l}\text { Physicians, nurses, dentists, nursing } \\
\text { technicians, oral health technicians } \\
\text { and assistants, and community } \\
\text { health workers }\end{array}$ & WHOQOL-bref & $\begin{array}{l}\text { Sociodemographic and } \\
\text { work data }\end{array}$ \\
\hline Morais et al. ${ }^{28}$ & $\begin{array}{l}\text { Minas } \\
\text { Gerais }\end{array}$ & $122 ; 71.9 \% ; 28.1 \%$ & 89 & Physicians & WHOQOL-bref & $\begin{array}{c}\text { Sociodemographic } \\
\text { work data and burnout } \\
\text { questionnaire }\end{array}$ \\
\hline
\end{tabular}

$\mathrm{F}=$ female; $\mathrm{M}=$ male; WHOQOL = World Health Organization Quality of Life instrument; $\mathrm{QWL}=$ quality of work life.

Table 4. Risk of bias assessed using the JBI critical assessment tool for systematic reviews, cross-sectional studies version ${ }^{22}$

\begin{tabular}{|c|c|c|c|c|c|c|c|c|c|c|}
\hline Author & 1 & 2 & 3 & 4 & 5 & 6 & 7 & 8 & $\%$ Yes & Risk \\
\hline Kluthcovsky et al. ${ }^{30}$ & $\sqrt{ }$ & $\sqrt{ }$ & NA & $\sqrt{ }$ & NA & NA & $\sqrt{ }$ & $\sqrt{ }$ & 100 & Low \\
\hline Vasconcelos and Costa-Val. ${ }^{31}$ & $\sqrt{ }$ & -- & NA & $\sqrt{ }$ & NA & NA & $\sqrt{ }$ & $\sqrt{ }$ & 80 & Low \\
\hline Figueiredo et al. ${ }^{27}$ & $\sqrt{ }$ & -- & NA & $\sqrt{ }$ & NA & NA & $\sqrt{ }$ & $\sqrt{ }$ & 80 & Low \\
\hline Ursine et al. ${ }^{33}$ & $\sqrt{ }$ & $\sqrt{ }$ & NA & $\sqrt{ }$ & NA & NA & $\sqrt{ }$ & $\sqrt{ }$ & 100 & Low \\
\hline Fernandes et al. ${ }^{26}$ & $\sqrt{ }$ & -- & NA & $\sqrt{ }$ & NA & NA & $\sqrt{ }$ & $\sqrt{ }$ & 80 & Low \\
\hline
\end{tabular}

1) Were the inclusion criteria in the sample clearly defined?; 2) Were the study subjects and scenario described in detail?; 3) Was exposure measured in a valid and reliable way?; 4) Were objective standard criteria used to measure the condition?; 5) Were confounding factors identified?; 6) Were the strategies to manage confounding factors informed?; 7) Were the results measured in a valid and reliable way?; 8) Was an adequate statistical analysis used?. $\sqrt{ }=$ yes; -- = no; NA = not applicable. 
working conditions, work capacities, work opportunity, social integration, respect for workplace laws, working life space and social relevance. ${ }^{34}$ These authors ${ }^{27}$ observed that the mean overall QWL score was 6.72 points, and fair compensation and working conditions were the domains most affected.

Table $5^{26,30-33}$ presents the results from extraction of the overall quality-of-life scores and the values obtained for each of the dimensions of the WHOQOL-bref and WHOQOL-100 questionnaires. Although these instruments were used in the studies by Teles et al. ${ }^{29}$ and Morais et al., ${ }^{28}$ their data were not included in Table 5 because they were presented as percentages measured in the quality-of-life domains. The study by Teles et al. ${ }^{29}$ focused on assessing the results among professionals with low quality of life, and an overall score of 6.72 was obtained. These authors indicated that community health workers had moderate quality of life. Morais et al. ${ }^{28}$ observed that physicians presented unsatisfying quality of life in the physical, social and environmental domains and an overall score of $14.5 \pm 2.2$.

\section{Complementary statistical analysis}

Only five studies ${ }^{26,30-33}$ presented sufficient mean and standard deviation data for the complementary analysis. Three studies that were included in the descriptive synthesis ${ }^{27-29}$ were not included in this stage for the following reasons: one study used a different instrument, ${ }^{27}$ another study presented data on workers with low quality of life $^{29}$ and another study described its data in a manner that prevented grouping in the complementary analysis. ${ }^{28}$

Figure 2A shows the quality-of-life scores reported in the eligible studies based on the WHOQOL-bref questionnaire. Through estimating weighted means according to sample sizes, it was found that the total quality-of-life score from the WHOQOL-bref questionnaire was $71.74(\mathrm{SD}=3.27)$. The environmental domain was the most affected (mean $=56.12$; $\mathrm{SD}=2.33$ ), followed by the psychological (mean $=73.79$; $\mathrm{SD}=1.51$ ), social relationships (mean $=75.00 ; \mathrm{SD}=2.03$ ) and physical health domains (mean = 75.86; $\mathrm{SD}=3.46)$.

Figure $2 \mathrm{~B}$ presents the quality-of-life scores reported in the eligible studies based on the WHOQOL-100 questionnaire. Through estimating weighted means according to sample size, it was observed that the physical domain was the most affected (mean $=14.29$; SD $=0.21)$, followed by the environmental $($ mean $=14.32 ; \mathrm{SD}=0.31)$, psychological (mean $=15.36 ; \mathrm{SD}=0.04)$, social relationship (mean $=15.92 ; \mathrm{SD}=0.31)$, spiritual $($ mean $=16.74 ; \mathrm{SD}=0.06)$ and level of independence domains ( mean $=17.07 ; \mathrm{SD}=0.08$ ).

\section{DISCUSSION}

This systematic review aimed to identify the levels of quality of life among Family Health Strategy workers. The studies included mainly used the instruments developed by the World Health Organization (WHOQOL-100 and WHOQOL-bref). It was seen

Table 5. Summary of the main results from the eligible studies included in the complementary analysis

\begin{tabular}{|c|c|c|c|c|}
\hline Author & Overall quality of life & Dimensions assessed & Results & Main conclusions \\
\hline \multirow{4}{*}{ Kluthcovsky et al. ${ }^{30}$} & \multirow{4}{*}{$69.6 \pm 14.5$} & Physical & $74.2 \pm 13.2$ & \multirow{4}{*}{$\begin{array}{c}\text { The sociodemographic variables and the domains did } \\
\text { not fully explain the variance in quality of life. }\end{array}$} \\
\hline & & Social & $75.8 \pm 14.2$ & \\
\hline & & Environmental & $54.1 \pm 12.0$ & \\
\hline & & Psychological & $74 \pm 11.4$ & \\
\hline \multirow{4}{*}{$\begin{array}{l}\text { Vasconcelos and } \\
\text { Costa-Val }\end{array}$} & \multirow{4}{*}{$3.98 \pm 0.65$} & Physical & $82.8 \pm 12$ & \multirow{4}{*}{$\begin{array}{c}\text { The study presented negative results only for the } \\
\text { environmental dimension. }\end{array}$} \\
\hline & & Social & $77 \pm 18$ & \\
\hline & & Psychological & $76 \pm 12.7$ & \\
\hline & & Environmental & $59.5 \pm 12.5$ & \\
\hline \multirow{6}{*}{ Miranzi et al. ${ }^{32}$} & \multirow{6}{*}{ Not informed } & Physical & $14.53 \pm 2.35$ & \multirow{6}{*}{$\begin{array}{l}\text { The worst results were found in the physical and } \\
\text { environmental domains. The main complaints from } \\
\text { the participants were lack of bonding, insecurity in the } \\
\text { workplace, number of employment links and wages. }\end{array}$} \\
\hline & & Psychological & $15.32 \pm 2.34$ & \\
\hline & & Level of social dependence & $17.16 \pm 1.95$ & \\
\hline & & Environmental & $15.67 \pm 2.24$ & \\
\hline & & Spiritual & $14.47 \pm 1.76$ & \\
\hline & & & $16.67 \pm 3.23$ & \\
\hline \multirow{4}{*}{ Ursine et al. ${ }^{33}$} & \multirow{4}{*}{$76.7 \pm 13.4$} & Physical & $74 \pm 12.3$ & \multirow{4}{*}{$\begin{array}{l}\text { The environmental domain presented intermediate } \\
\text { results, while the others showed positive results. }\end{array}$} \\
\hline & & Social & $71.5 \pm 16.7$ & \\
\hline & & Psychological & $71.5 \pm 13.6$ & \\
\hline & & Environmental & $58.0 \pm 11.4$ & \\
\hline \multirow{6}{*}{ Fernandes et al. ${ }^{26}$} & \multirow{6}{*}{$16.7 \pm 2.2$} & Physical & $14.1 \pm 1.9$ & \multirow{6}{*}{$\begin{array}{l}\text { The results of the questionnaire showed little or no } \\
\text { negative impact on the domains. }\end{array}$} \\
\hline & & Psychological & $15.4 \pm 2.0$ & \\
\hline & & Level of social dependence & $17.0 \pm 1.6$ & \\
\hline & & Environmental & $16.2 \pm 2.1$ & \\
\hline & & \multirow[t]{2}{*}{ Spiritual } & $14.2 \pm 1.9$ & \\
\hline & & & $16.8 \pm 2.6$ & \\
\hline
\end{tabular}


that graduate professionals and community health workers were affected differently regarding the quality-of-life domains. Most studies using WHOQOL-bref to investigate the quality of life of community health workers showed that the environmental dimension was the one most affected. However, the studies using WHOQOL-100 also included physicians and nurses, and indicated that the physical dimension was the one most affected.

The environmental dimension, which was most affected among community health workers, relates to freedom, safety, financial resources, access to health, social support, recreation, transportation and environmental quality. ${ }^{35}$ The qualitative studies by Souza and Freitas ${ }^{36}$ and Almeida, Peres and Fonseca ${ }^{37}$ corroborated this result, thus showing that community health workers felt unsafe when working with families because they were exposed to urban violence without any type of protection against this reality, which was present in several regions.

There was also a feeling of insecurity and uncertainty regarding the job, which was observed by Souza and Freitas ${ }^{36}$ and Figueiredo et al., ${ }^{27}$ which helps to understand the low level of the environmental domain among community health workers. Another important factor in understanding the environmental dimension as the one most affected among community health workers is income (or availability of financial resources). The remuneration of community workers is the lowest among family health professionals ${ }^{38}$ and their monthly income may be considered to be close to ${ }^{38}$ or below $^{39}$ the average wage reality of Brazilians, varying according to the region of the country. Therefore, considering that exposure to violence is an occupational risk for community health workers, ${ }^{38}$ these professionals should receive compensatory payment (hazard pay). Although this measurement does not have any direct impact on the quality of life, it may contribute to the remuneration for the work performed by this professional category. Another strategy for improvement of community health workers' quality of life would be for their home visits to be made in pairs.

For physicians and nurses, the physical dimension presented the worst results. This dimension refers to pain, discomfort, sleep quality, fatigue, medication dependence and the ability to work. ${ }^{35}$ Physicians and nurses are the professionals working in primary healthcare among whom the highest number of studies on work burnout have been conducted. ${ }^{40}$ Compared with other primary healthcare professionals, they present the highest work stress. ${ }^{42}$ There is high prevalence of work burnout among graduate professionals. ${ }^{40,42}$ Silva et al $^{42}$ indicated that the prevalence of burnout was $64 \%$ and the prevalence of inability to work was $32 \%$ among nurses, physicians, dentists and social workers. Lima, Farah and Teixeira ${ }^{40}$ studied physicians, nurses and dentists working in the Family Health Strategy in a large city in the state of Minas Gerais, Brazil, and found that more than half of the professionals presented burnout syndrome.
The studies included in this systematic review used different instruments to assess the quality of working life, from unspecific ones (WHOQOL-100 and WHOQOL-bref) to a specific instrument for the work environment (Walton's QWL). Regarding the unspecific instruments included in this systematic review, it is worth noting that both were developed by the same group of researchers: WHOQOL-bref is the short version of WHOQOL-100. ${ }^{35}$ The authors of these instruments suggested that both are effective in assessing quality of life within the concept determined by the World Health Organization, but that the short version would be indicated for assessing work routines in epidemiological studies. ${ }^{35}$

The existence of several instruments lies within the very essence of the concept of quality of life: polysemic, imperfect and dynamic. ${ }^{43}$ The specific instrument used by Figueiredo et al. ${ }^{27}$ (Walton's QWL) comes from the conception of work-related quality of life that has been observed within a context of labor movements towards more legal certainty in the workplace, better working conditions and adequate remuneration. ${ }^{34}$ However, the creation of this concept, and consequently the instrument, was linked to a historical and cultural particularity of a region, with constant updates and new propositions for the concept of work-related quality of life. ${ }^{44}$

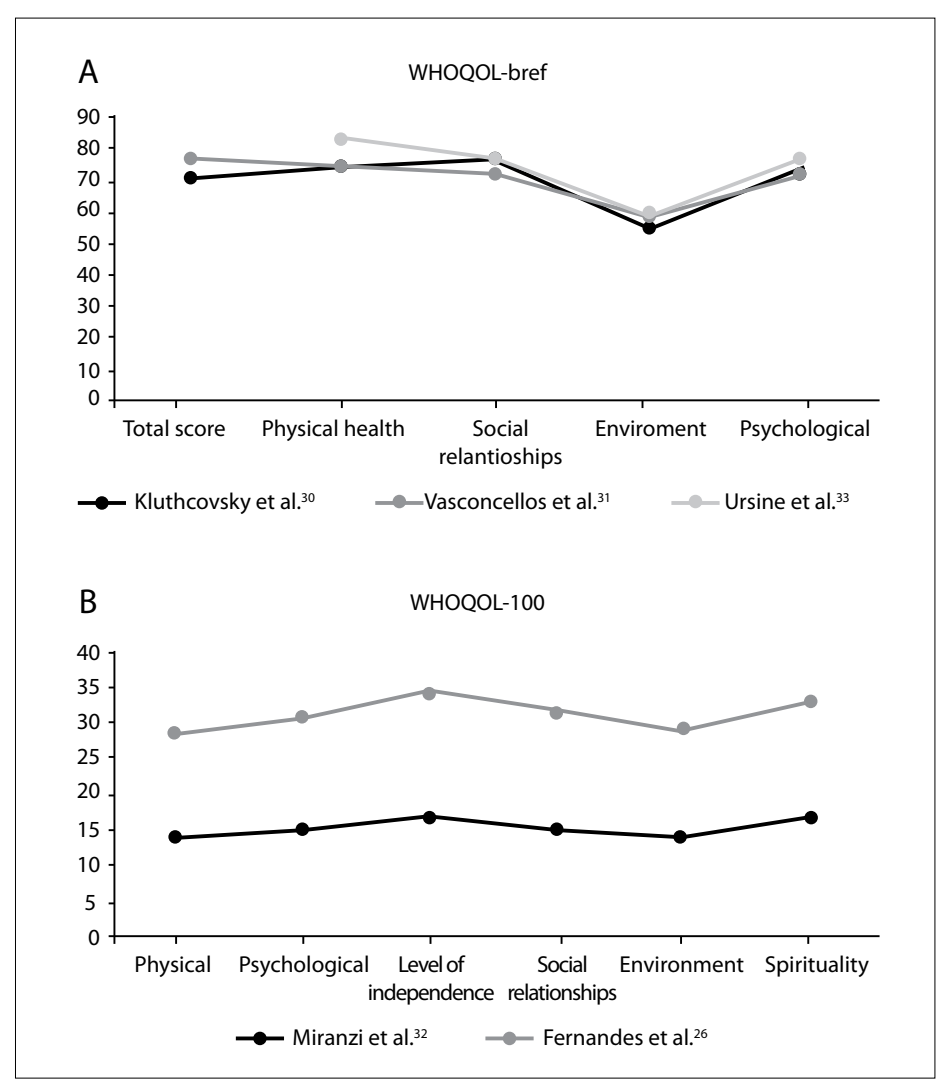

Figure 2. A) Levels of quality-of-life domains reported in the eligible studies based on the World Health Organization Quality of Life (WHOQOL)-bref questionnaire; B) Levels of quality-of-life domains reported in the eligible studies based on the WHOQOL-100 questionnaire. 
Therefore, the systematic review and meta-synthesis by Pennisi et al. ${ }^{45}$ indicated that assessing the quality of life of Family Health Strategy professionals should include the following factors: working conditions, work processes, interpersonal relationships, personal aspects, work context, work overload and autonomy.

This study is not free from limitations. The first of them related to the heterogeneity observed in the eligible studies, caused by the use of different questionnaires to assess the quality of life (WHOQOL-bref, WHOQOL-100 and Walton's QWL), as previously discussed. Moreover, the results were presented differently (percentages or means and standard deviations), which prevented inclusion of a greater number of studies in the complementary analysis. Another limitation was that the studies were directed towards different professionals, who present professional and social particularities. Lastly, there was an important difference in the number of questionnaires answered in each study, ranging from 42 to 762 , which may explain the heterogeneity in the findings. Thus, although the results obtained are consistent, they should be analyzed carefully and further studies are required, in order to assess the true impact of the working conditions of Family Health Strategy professionals on their quality of life.

\section{CONCLUSION}

Quality-of-life domains are affected differently among primary healthcare professionals working in family health teams. While physicians and nurses are more affected in the physical domain, community health workers are affected in the environmental domain. This shows that actions in favor of the quality of life of family health professionals cannot be standardized, but the particularities of each professional category must be considered.

Another important factor is the influence of the region covered by the family health team on the quality of life of community health workers. There is an important paradox in considering this relationship and the promotion of quality of life for this professional category because the region is itself the workplace of community health workers, but is also the main factor responsible for interfering with their quality of life.

\section{REFERENCES}

1. Scherer MDA, Marino SRA, Ramos FRS. Rupturas e resoluções no modelo de Atenção à Saúde: reflexões sobre a estratégia saúde da família com base nas categorias kuhnianas [Ruptures and resolutions in the health care model: reflections on the Family Health Strategy based on Kuhn's categories]. Interface (Botucatu). 2005;16(9):53-66. https://doi.org/10.1590/S1414-32832005000100005.

2. Brasil. Conselho Nacional de Secretários de Saúde. Legislação Estruturante do SUS/Conselho Nacional de Secretários de Saúde. Brasília: CONASS;
2011. Available from: https://www.conass.org.br/bibliotecav3/pdfs/ colecao2011/livro_1.pdf. Accessed in 2021 (Feb 26).

3. Silva GL. A família no processo de cuidar. Revista Ciência e Desenvolvimento. 2019;12(2):369-85.

4. Silva-Roosli ACB, Athayde MG. Trabalho e Psicodinâmica do Reconhecimento no Cotidiano da Estratégia de Saúde da Família. In: Assunção AÁ, Brito J, editores. Trabalhar na Saúde: experiências cotidianas e desafios para a gestão do trabalho e do emprego. 22a ed. Rio de Janeiro: FIOCRUZ; 2011. p. 29-37.

5. Pinto LF, Giovanella L. Do Programa à Estratégia Saúde da Família: expansão do acesso e redução das internações por condições sensíveis à atenção básica (ICSAB) [The Family Health Strategy: expanding access and reducing hospitalizations due to ambulatory care sensitive conditions (ACSC)]. Cienc Saude Colet. 2018;23(6):1903-13. PMID: 29972498; https://doi.org/10.1590/1413-81232018236.05592018.

6. Macinko J, Harris MJ, Phil D. Brazil's family health strategy - delivering community-based primary care in a universal health system. N Engl J Med. 2015;372(23):2177-81. PMID: 26039598; https://doi.org/10.1056/ NEJMp1501140

7. Viacava F, Bellido JG. Condições de saúde, acesso a serviços e fontes de pagamento, segundo inquéritos domiciliares [Health, access to services and sources of payment, according to household surveys]. Cienc Saude Colet. 2016;21(2):351-70. PMID: 26910144; https://doi. org/10.1590/1413-81232015212.19422015. Erratum in: Cien Saude Colet. 2017;22(4):1383-6.

8. Brasil. Sala de Apoio a Gestão Estratégica do Ministério da Saúde. Saúde Mais Perto de Você - Atenção Primária à Saúde. 2020. Available from: https://sage.saude.gov.br/\#. Accessed in 2021 (Feb 26).

9. Junqueira S. Competências profissionais na estratégia saúde da família e o trabalho em equipe. São Paulo: 2012. Available from: https://www. unasus.unifesp.br/biblioteca_virtual/esf/1/modulo_politico_gestor/ Unidade_9.pdf. Accessed in 2021 (Feb 26).

10. Zarei E, Ahmadi F, Sial MS, et al. Prevalence of burnout among primary health care staff and its predictors: A study in Iran. Int J Environ Res Public Health. 2019;16(12):2249. PMID: 31242691; https://doi. org/10.3390/ijerph16122249.

11. Khammar A, Dalvand S, Hashemian AH, et al. Data for the prevalence of nurses' burnout in Iran (a meta-analysis dataset). Data Brief. 2018;20:1779-86. PMID: 30294624; https://doi.org/10.1016/j. dib.2018.09.022

12. Rotenstein $L S$, Torre $M$, Ramos MA, et al. Prevalence of Burnout Among Physicians: A Systematic Review. JAMA. 2018;320(11):1131-50. PMID: 30326495; https://doi.org/10.1001/jama.2018.12777.

13. Albuquerque FJBD, Melo CDF, Araújo Neto JLD. Evaluation of burnout syndrome in professionals of the Family Health Strategy Service in João Pessoa-Paraíba. Psicol Reflex Crit. 2012;25(3):542-9. https://doi. org/10.1590/S0102-79722012000300014.

14. Martins LF, Laport TJ, Menezes V de P, Medeiros PB, Ronzani TM. Esgotamento entre profissionais da Atenção Primária à Saúde [Burnout 
syndrome in primary health care professionals]. Cien Saude Colet. 2014;19(12):4739-50. PMID: 25388182; https://doi.org/10.1590/1413812320141912.03202013.

15. Cardoso ACM. O trabalho como determinante do processo saúdedoença. Tempo soc. 2015;27(1):73-93. https://doi.org/10.1590/0103207020150110.

16. Kimura M, Carandina DM. Desenvolvimento e Validação de uma versão reduzida do instrumento para avaliação de qualidade de vida no trabalho de enfermeiros em hospitais. Rev Esc Enferm USP. 2009;43(esp):1044-54. https://doi.org/10.1590/S008062342009000500008 .

17. Fernandes JS, Miranzi SSC, Iwamoto HM, Tavares DMS, Santos CB. Qualidade de vida dos enfermeiros das equipes de saúde da família: a relação das variáveis sociodemográficas. Texto \& Contexto - Enferm. 2010;19(3):43442. https://doi.org/10.1590/S0104-07072010000300004.

18. Ribeiro LA, Santana LC. Qualidade de vida no Trabalho: fator decisivo para o sucesso organizacional. Revista de Iniciação Científica - RIC Cairu. 2015;2(2):75-96. Available from: https://www.cairu.br/riccairu/ pdf/artigos/2/06_QUALIDADE_VIDA_TRABALHO.pdf. Accessed in 2021 (Feb 26).

19. Anderson RJ, Bloch S, Armstrong M, Stone PC, Low JT. Communication between healthcare professionals and relatives of patients approaching the end-of-life: A systematic review of qualitative evidence. Palliat Med. 2019;33(8):926-41. PMID: 31184529; https:// doi.org/10.1177/0269216319852007.

20. Liberati A, Altman DG, TetzlaffJ, et al. The PRISMA statement for reporting systematic reviews and meta-analyses of studies that evaluate healthcare interventions: explanation and elaboration. BMJ. 2009;339:b2700. PMID: 19622552; https://doi.org/10.1136/bmj.b2700.

21. Aromataris E, Munn Z, editors. JBI Manual for Evidence Synthesis. Adelaide: JBl; 2020. https://doi.org/10.46658/JBIMES-20-01.

22. Moola S, Munn Z, Tufanaru C, et al. Chapter 7: Systematic reviews of etiology and risk. In: Aromataris E, Munn Z, editors. Joanna Briggs Institute Reviewer's Manual. Adelaide The Joanna Briggs Institute; 2017. p. 217-67. https://doi.org/10.46658/JBIMES-20-08.

23. Mota CM, Dosea GS, Nunes PS. Avaliação da presença da Síndrome de Burnout em Agentes Comunitários de Saúde no município de Aracaju, Sergipe, Brasil [Assessment of the prevalence of burnout syndrome in community health agents of the city of Aracaju in the state of Sergipe, Brazil]. Cien Saude Colet. 2014;19(12):4719-4726. PMID: 25388180; https://doi.org/10.1590/1413-812320141912.02512013.

24. Ejlertsson L, Heijbel B, Ejlertsson G, Andersson I. Recovery, worklife balance and work experiences important to self-rated health: A questionnaire study on salutogenic work factors among Swedish primary health care employees. Work. 2018;59(1):155-163. PMID: 29439377; https://doi.org/10.3233/WOR-172659.

25. Martín J, Cortés JA, Morente M, et al. Características métricas del Cuestionario de Calidad de Vida Profesional (CVP-35) [Metric characteristics of the Professional Quality of Life Questionnaire [QPL-
35] in primary care professional]. Gac Sanit. 2004;18(2):129-36. PMID: 15104973; https://doi.org/10.1016/s0213-9111(04)71817-8.

26. Fernandes JS, Miranzi SSC, Iwamoto HH, Tavares DMS, Santos CB. A relação dos aspectos profissionais na qualidade de vida dos enfermeiros das equipes Saúde da Família. Rev Esc Enferm USP. 2012;46(2):404-12. https://doi.org/10.1590/S0080-62342012000200019.

27. Figueiredo IM, Neves DS, Montanari D, Camelo SHH. Qualidade de vida no trabalho: percepções dos agentes comunitários de equipes de saúde da família. Rev Enferm UERJ. 2009;17(2):262-7.

28. Morais AJD, Teles CB, Rocha LF, Silveira MF, Pinho L. Síndrome de Burnout em Médicos de Estratégia Saúde da Família de Montes Claros, MG, e Fatores Associados. Rev Bras Med Fam Comunidade. 2018;13(40):1-15. https://doi.org/10.5712/rbmfc13(40)1751.

29. Teles MA, Barbosa MR, Vargas AM, et al. Psychosocial work conditions and quality of life among primary health care employees: a cross sectional study. Health Qual Life Outcomes. 2014 May 15;12:72. PMID: 24884707; https://doi.org/10.1186/1477-7525-12-72.

30. Kluthcovsky ACGC, Takayanagui AMM, Santos CB, Kluthcovsky FA. Avaliação da qualidade de vida geral de agentes comunitários de saúde: a contribuição relativa das variáveis sociodemográficas e dos domínios da qualidade de vida. Rev Psiquiatr Rio Gd Sul. 2007;29(2):176183. https://doi.org/10.1590/S0101-81082007000200009.

31. Vasconcellos NPC, Costa-Val R. Avaliação da qualidade de vida dos agentes comunitários de saúde de Lagoa Santa - MG. Rev APS. 2008;11(1):17-28. Available from: https://www.uff.br/nates/ files/2009/12/017-028.pdf. Accessed in 2021 (Feb 26).

32. Miranzi SSC, Mendes CA, Nunes AA, Iwamoto HH, Miranzi MAS, Tavares DMS. Qualidade de vida e perfil sociodemográfico de médicos da estratégia de saúde da família. Rev Med Minas Gerais. 2010;20(2):18997. Available from: http://rmmg.org/artigo/detalhes/312. Accessed in 2021 (Feb 26).

33. Ursine BL, Trelha CS, Nunes EFPA. O Agente Comunitário de Saúde na Estratégia de Saúde da Família: uma investigação das condições de trabalho e da qualidade de vida. Rev Bras Saude Ocup. 2010;35(122):32739. https://doi.org/10.1590/S0303-76572010000200015.

34. Walton RE. Quality of working life: what is it. Sloan Management Review. 1973;15(1):11-21

35. The World Health Organization Quality of Life Assessment (WHOQOL): development and general psychometric properties. Soc Sci Med. 1998;46(12):1569-85. PMID: 9672396; https://doi.org/10.1016/s02779536(98)00009-4.

36. Souza LRD, Freitas MDCSD. O agente comunitário de saúde: violência e sofrimento no trabalho a céu aberto. Revista Baiana de Saude Publica. 2011;35(1):96-109. http://files.bvs.br/upload/S/0100-0233/2011/ v35n1/a2100.pdf.

37. Almeida JFD, Peres MFT, Fonseca TL. The territory and implications of urban violence for the work process of community health agents in a primary healthcare unit. Saude Soc. 2019;28(1):207-21. https:// doi.org/10.1590/s0104-12902019170543. 
38. Araujo AF, Greco RM. Associação entre condições de trabalho e os Indicadores de Prazer e Sofrimento no cotidiano de trabalho de Agentes Comunitários de Saúde. APS. 2019;1(3):173-80. https://doi. org/10.14295/aps.v1i3.46.

39. Moreira KDS, Bezerra MLR, Nunes SFL, Teixeira CM de S. Riscos na rotina de trabalho de Agentes Comunitários de Saúde de uma Equipe de Saúde da Família. J Manag Prim Health Care. 2019;10:e8. https://doi. org/10.14295/jmphc.v10i0.955.

40. Lima ADS, Farah BF, Bustamante-Teixeira, MT. Análisis de la prevalencia del síndrome de burnout en profesionales de la atención primaria en salud. Trab Educ Saude. 2018;16(1):283-304. https://doi. org/10.1590/1981-7746-sol00099.

41. Atanes AC, Andreoni S, Hirayama MS, et al. Mindfulness, perceived stress, and subjective well-being: a correlational study in primary care health professionals. BMC Complement Altern Med. 2015;15:303. PMID: 26329810; https://doi.org/10.1186/s12906-015-0823-0.

42. Silva SC, Nunes MA, Santana VR, et al. A síndrome de burnout em profissionais da Rede de Atenção Primária à Saúde de Aracaju, Brasil [Burnout syndrome in professionals of the primary healthcare network in Aracaju, Brazil]. Cienc Saude Colet. 2015;20(10):3011-20. PMID: 26465844; https://doi.org/10.1590/1413-812320152010.19912014.

43. Minayo MC. Qualidade de vida e saúde como valor existencial [Quality of life and health as existential values]. Cienc Saude Colet. 2013;18(7):1868. PMID: 23984459; https://doi.org/10.1590/S141381232013000700001.

44. Martel JP, Dupuis G. Quality of work life:Theoretical and methodological problems, and presentation of a new model and measuring instrument. Soc Indic Res. 2006;77(2):333-68. https://doi.org/10.1007/s11205-0045368-4.

45. Pennisi PRC, Alves NC, Michelin PS, et al. The quality of life of family health professionals: a systematic review and meta-synthesis. Rev Bras Enferm. 2020;73(5):e20190645. PMID: 32667408; https://doi. org/10.1590/0034-7167-2019-0645.

Authors' contributions: Balabem ACCP: conceptualization (equal), data curation (equal), investigation (equal), validation (equal), visualization (equal), writing-original draft (equal) and writing-review and editing (equal); Oliveira MN: data curation (equal), investigation (equal), methodology (equal), validation (equal), visualization (equal), writingoriginal draft (equal) and writing-review and editing (equal); Herval AM: data curation (equal), formal analysis (equal), investigation (equal), validation (equal), visualization (equal), writing-original draft (equal) and writing-review and editing (equal); Bernardino IM: formal analysis (equal), investigation (equal), validation (equal), visualization (equal), writingoriginal draft (equal) and writing-review and editing (equal); Vieira WA: data curation (equal), methodology (equal), validation (equal), visualization (equal), writing-original draft (equal) and writing-review and editing (equal); Rodrigues RPCB: funding acquisition (equal), methodology (equal), validation (equal), visualization (equal), writingoriginal draft (equal) and writing-review and editing (equal); and Paranhos LR: conceptualization (equal), funding acquisition (equal), methodology (equal), supervision (equal), validation (equal), visualization (equal), writing-original draft (equal) and writing-review and editing (equal). All authors reviewed and approved the final version of the manuscript to be released

Sources of funding: This study was financed in part by Coordenação de Aperfeiçoamento de Pessoal de Nível Superior - Brasil (CAPES), under finance code 001. We are also grateful for the support of Conselho Nacional de Desenvolvimento Científico e Tecnológico - Brasil (CNPq), under finance code 307808/2018-1

\section{Conflict of interest: None}

Date of first submission: November 1, 2020

Last received: January 11, 2021

Accepted: February 9, 2021

\section{Address for correspondence:}

Luiz Renato Paranhos

Departamento Odontologia Preventiva e Comunitária, Universidade Federal de Uberlândia (UFU), Campus Umuarama

Av. Pará, 1.720 - Bloco 2G — Sala 1

Uberlândia (MG) — Brasil

CEP 38405-320

Tel. (+55 34) 99276-9292

E-mail: paranhos.Irp@gmail.com 